\title{
DISZKRÉT TERMELÉSI FOLYAMATOK ÚJRAÜTEMEZÉSI FELADATAINAK MEGOLDÁSA TÖBBCÉLÚ KERESŐ ALGORITMUSSAL
}

\author{
Kulcsár Gyula \\ egyetemi docens, Miskolci Egyetem, Informatikai Intézet, Alkalmazott Informatikai Intézeti Tanszék \\ 3515 Miskolc, Miskolc-Egyetemváros, e-mail: iitkgy@uni-miskolc.hu \\ Kulcsárné Forrai Mónika \\ egyetemi docens, Miskolci Egyetem, Informatikai Intézet, Alkalmazott Informatikai Intézeti Tanszék \\ 3515 Miskolc, Miskolc-Egyetemváros, e-mail: aitkfm@uni-miskolc.hu
}

\begin{abstract}
Absztrakt
A cikk a diszkrét termelési folyamatok újraütemezési feladatainak jellemzőit foglalja össze, és egy új kiterjesztett megoldási módszert mutat be. Az újraütemezés célja a gyártás közben bekövetkezett váratlan események kezelése azáltal, hogy egy adott idöszakra elöre elkészitett ütemterv módositott változatát készíti el. Ezt úgy kell megvalósitani, hogy a teljesitmény-mutatók megfelelö értékeket vegyenek fel és az eredeti ütemtervtöl való eltérés a lehetö legkisebb mértékü legyen. A probléma megoldására zárolási technikákat alkalmazó többcélú keresési módszert javasolunk.
\end{abstract}

Kulcsszavak: újraütemezés, keresö algoritmus, optimalizálás, gyártás, váratlan esemény

\begin{abstract}
The paper summarizes the features of rescheduling problems of the discrete production processes and describes a new extended solving method. The purpose of the rescheduling is to manage the unexpected events occurred during the manufacturing. The rescheduling process creates a modified version of the predictive schedule for a given time horizon. It is required that the performance indicators take up suitable values and the deviation from the original schedule should be as small as possible. To solve this problem, we propose an advanced multi-objective searching method by using locking techniques.
\end{abstract}

Keywords: rescheduling, searching algorithm, optimization, manufacturing, unexpected event

\section{Bevezetés}

A termelésütemezési modellek és módszerek fejlesztésére irányuló kutatások elméleti és gyakorlati szempontból egyaránt nagyon fontosak. A témához kapcsolódó optimalizálási feladatok más kutatási területek problémáival is szoros kapcsolatban állnak. Ilyenek például a logisztikai, erőforrás-tervezési és üzleti folyamatokkal kapcsolatos optimalizálási problémák [2, 4].

Az utóbbi években újra nagy hangsúlyt kapott az elöidejủ és a valós idejü ütemezés összehangolása a Kiber-fizikai rendszerek és az Ipar 4.0 keretében. Az ilyen integráció egyik kulcskérdése az, hogy a bizonytalanságok és váratlan események hogyan kezelhetők hatékonyan. A folyamatok irányításának egyik fontos operatív módszere az átütemezés - vagy más néven újraütemezés (rescheduling) -, amely 
az aktuális állapot alapján a folyamatok hátralévő - még el nem végzett - folyamatelemeinek végrehajtását részleges vagy teljes mértékben újratervezi. Az alapvető újraütemezési stratégiákról az [5] és a [7] publikációk részletes áttekintést nyújtanak.

Az újraütemezés lényege az, hogy az eredeti ütemezési feladat jelentős mértékben kiterjesztésre kerül azáltal, hogy új korlátozások és új célok jelennek meg a klasszikus ütemezési feladatok elemei mellett. A kiterjesztett probléma döntési változóinak értékkészletét (megoldásterét) az új feltételek jelentősen módosítják, és a feladat megoldását nehezítik a gyártásirányítás speciális követelményei. Ide sorolhatók például a gépátállítási, az erőforrás-kihasználtsági, anyagellátási és anyagmozgatási igények [1]. Az újraütemezési modellekkel szemben támasztott fontos követelmény, hogy a beavatkozási döntések eredményei az új korlátozásoknak és új céloknak egyaránt megfeleljenek. Az újraütemezési koncepciókról jó összefoglalást adnak például az [1] és a [6] publikációk.

\section{Az újraütemezési feladatok jellemzői}

Egy diszkrét gyártórendszerben végrehajtandó folyamatok ütemezése során feltételezzük, hogy adott a gyártórendszer aktuális állapota és az érvényes korlátozások halmaza. Ide tartoznak például az elsődleges technológiai és egyéb erőforrások, azok korlátozott képességei és kapacitásai, a rendelkezésre állások időintervallumai, a müveletek sorrendjének definíciói és további speciális feltételek. Az alap prediktív ütemezési feladatban a végrehajtásra kiadott belső rendelések (production order) teljesítéséhez gyártási munkákat (job) és mủveleteket (operation) kell definiálni, továbbá ezek elvégzéséhez alkalmas erőforrásokat (resource) kell hozzárendelni. Minden gyártási eseményhez indítási és befejezési időpontokat kell hozzárendelni úgy, hogy a korlátozások betartásával a gyártási folyamat teljesítményét mérő mutatók (key performance indicators, KPI) kvázi-optimálisak legyenek. A KPI mutatók fejezik ki ebben az optimalizálási feladatban a menedzsment megfogalmazott céljait.

A prediktív ütemterv önmagában nem garantálja az ütemezett időszakban a gyártási folyamat optimális végrehajtását, mivel a belső gyártási környezet és a külső üzleti környezet elkerülhetetlen bizonytalan viselkedése miatt szükséges a gyártás valós idejű folyamatos irányítása. A fellépő váratlan események káros hatásának csökkentése érdekében számos korrekciós beavatkozási döntést kell meghozni és végrehajtani. Az ilyen beavatkozást igénylő szituációk megkövetelik a végrehajtás alatt álló, előzetesen jól megtervezett ütemterv felülvizsgálatát és módosítását, ezáltal a folyamatok és müveletek újraütemezését [4].

Az újraütemezés tehát az elindított és végrehajtás alatt álló gyártási ütemterv aktualizálása, korrigálása és újratervezése, amely az irányítórendszer egyik beavatkozási funkciója.

\section{Az újraütemezési feladatok megoldása többcélú kereső algoritmussal}

Az általunk javasolt újraütemezési koncepció lényege az, hogy az előidejü ütemezési módszerek kiterjesztésével a speciális követelményeket támasztó újraütemezési feladatok is hatékonyan megoldhatók. A kiterjesztést új korlátfeltételek és új célfüggvények bevezetésével valósítottuk meg.

Az újraütemezési feladatban adott egy érvényben lévő gyártási finomprogram, ami leírja a gyártási folyamat elvárt menetét, valamint adottak az ehhez tartozó tervezett teljesítménymutatók. Ezek kezdeti feltételként jelennek meg, és ez a halmaz lesz az összehasonlítás alapja. Szintén bemenő információként adott az aktuális helyzetet pontosan definiáló termelési finomprogram, amelyben a ténylegesen bekövetkezett események és az azokból eredö állapotváltozások sorozatának megfelelö időadatok szerepelnek. 
Az újraütemezéskor fontos, hogy az érvényben lévő ütemtervnek az újraütemezés időpontja előtt végrehajtott, vagy elkezdett része nem változtatható meg. Ugyanígy definiálható egy olyan jövőre vonatkozó időintervallum is, amelyben a változtatásra vonatkozó tilalom szintén érvényes. Ez azt fejezi ki, hogy az újraütemezés elkezdésének időpontja és az új ütemterv érvényesítésének időpontja közötti időszakban (reagálási időszak) a rendszer még az eredeti ütemterv szerint fog müködni. Az érintett gyártási műveletek, munkák és belső megrendelések hatást fognak gyakorolni az új ütemtervre is. Például, ha egy adott terméktípus egy számára kiválasztott gyártási útvonalon már elindult, akkor a hátralévő még meg nem kezdett gyártási müveletei a kezdeti erőforrás-alternatíváknak csak egy részhalmazára irányíthatók át. Ilyen esetekben az idő elörehaladásának függvényében csökkennek a beavatkozási lehetôségek.

Az újraütemezés során a módosított termelési ütemterv értékelésének szempontjai közé betettünk olyan új KPI elemeket (célfüggvényeket), amelyek kifejezik a módosítás mértékét. Ezeket minimalizálandó alakban definiáltuk, ezáltal teljesíthető az az igény, hogy minél kisebb mértékü változtatással maximális javulást érjünk el, stabil és átlátható („rángatástól mentes”) gyártás valósuljon meg.

A korábban kidolgozott többcélú keresési módszereinket vettük alapul. Ezek kellően rugalmasak voltak ahhoz, hogy kisebb továbbfejlesztéssel az újraütemezés speciális elvárásait is teljesítsék a fentebb vázolt módszerek beépítésével. A következő fejlesztéseket végeztük el:

- a szimulációs modell kiterjesztése;

- a célfüggvények körének kibővítése a változtatások mértékének csökkentése érdekében;

- zárolási technikák bevezetése a tiltott változtatások elkerülése érdekében;

- kereső operátorok fejlesztése a KPI mutatók javítása érdekében.

A többcélú keresési módszer alapvetően egy gyors szimulációra alapozott problématértranszformációra támaszkodik, melynek lényege az, hogy a megoldás keresésekor egy egyszerüsített ütemterv készül a döntési változók értékei alapján. Ez rögzíti a munkák technológiai útvonalát, az allokált erőforrásokat, valamint a végrehajtási sorrendeket. Ezekből kiindulva a teljes ütemterv végrehajtásának szoftveres szimulációja kiszámítja az egyes elemekhez tartozó indítási és befejezési időpontokat. Ez a módszer az újraütemezés során úgy működik, hogy a szabálybázisra épített szimulációs algoritmus a már rögzített időadatokat figyelembe veszi a múltbeli gyártási eseményeknél, és csak az ismeretlen (jövőbeli várható) időadatokat számítja ki.

A [3] dolgozatban bemutatott prediktív ütemezésre alkalmazott többcélú kereső módszerbe beillesztettük az újraütemezés új követelményeit kielégítő elemeket. A változások mértékének minimalizálása érdekében a következő célfüggvényeket definiáltuk:

1. Az eredetitől eltérő útvonal bejárására ütemezett munkák száma;

2. Az eredetitől legalább egy eltérő gépre ütemezett munkák száma;

3. Az eredetileg tervezett csúszás vagy időbeliség szempontjából megváltoztatott munkák száma;

4. Az újraütemezés következtében csúszóvá váló munkák száma;

5. Az 1. pontban leírt feltételnek megfelelő munkával rendelkező megrendelések száma;

6. A 2. pontban leírt feltételnek megfelelő munkával rendelkező megrendelések száma;

7. Az eredetihez képest megváltoztatott befejezési státuszú megrendelések száma;

8. Az újraütemezés következtében csúszóvá váló megrendelések száma;

9. A megváltozott átállásokkal érintett gépek és munkahelyek száma;

10.Az újraütemezés következtében új átállásokkal terhelt gépek és munkahelyek száma. 
A felsorolt változást kifejező mutatók és a gyártási hatékonyságot számszerüsítő mutatók együttesen alkotják a célfüggvény-rendszert, amely minősíti a módosított termelési ütemtervet. A különböző célfüggvények fontosságának kifejezésére olyan prioritásértékeket használunk, amelyek aktuális értékét a felhasználó állíthatja be. A kereső motor a prioritások alapján a relatív változásra alapozott összehasonlító és eredményértékelő módszert alkalmazza [3].

Az újraütemezés az aktuális szituációt leíró ütemtervből indul ki, és elemi módosítások sorozatával alkotja meg az új ütemtervet. Így az előidejü ütemezésre használt többcélú keresési technikák (tabu keresés, genetikus algoritmus stb.) az újraütemezési feladatok megoldására is használhatók. Újraütemezéskor azonban azt is figyelembe kell venni, hogy a kiindulási ütemtervnek a múltban bekövetkezett része, valamint az új ütemterv elkészítéséhez és indításához szükséges időintervallumba eső része nem módosítható. Az újraütemezés sebességének növelése érdekében a tiltott módosítások a keresés előtt elemzésre kerülnek. A megengedett alternatívák rendszerezett formában beépülnek a modell kapcsolatrendszerébe. Ezáltal a keresés közbeni döntési helyzetekben a választható alternatívák között csak az új feltételeket is maradéktalanul kielégítő lehetőségek jelennek meg. Az újraütemezési korlátozások ilyen irányú kibővítését zárolási technikák alkalmazásával valósítottuk meg. A zárolási szabályok egyaránt vonatkozhatnak munkákra, megrendelésekre és gépekre (munkahelyekre). Például adott munka esetében elöírható, hogy mely operációjától kezdve engedélyezett a változtatás. Ehhez hasonlóan, adott munkahely esetében elöírható, hogy a végrehajtási sorában mely müvelettől kezdve lehet változtatást elvégezni. Adott megrendelés esetében a hozzá tartozó zárolt munkák attribútumaiból egyértelmüen következik a zárolás mértéke és formája.

Az előidejű ütemezésre használt szomszédsági operátorokat továbbfejlesztettük annak érdekében, hogy a zárolásokat figyelembe vegyék. Ennek köszönhetően a többcélú heurisztikus kereső algoritmus alkalmassá vált az újraütemezési feladatok megoldására.

\section{4. Összefoglalás}

A cikkben bemutatott újraütemezési koncepciót felhasználva hatékonyan kezelhetők mind az előidejü termelésütemezési, mind az újraütemezési feladatok. A javasolt módszer végrehajtás-szimulációra alapozott problématér-transzformációra, zárolási technikákra és többcélú keresési algoritmusra támaszkodva müködik. A kifejlesztett szoftver igazolta, hogy a vázolt modell hatékonyan támogatja a technológiai alternatívák kezelését, az erőforrások allokálását és a gyártási feladatok végrehajtásának időbeli ütemezését és újraütemezését.

\section{Köszönetnyilvánítás}

A kutató munka a Miskolci Egyetem stratégiai kutatási területén müködő Mechatronikai és Logisztikai Kiválósági Központ keretében valósult meg.

\section{Irodalom}

[1] Aytug, H., Lawley, M., A., McKay, K., Mohan, S., Uzsoy, R.: Executing Production Schedules in the Face of Uncertainties: A Review and some Future Directions, European Journal of Operational Research 2005, 161:86-110. https://doi.org/10.1016/j.ejor.2003.08.027

[2] Bányai, Á., Illés, B., Glistau, E., Machado, N., Isaias, C., Tamás, P., Manzoor, F., Bányai, T.: Smart Cyber-Physical Manufacturing: Extended and Real-Time Optimization of Logistics Resources in Matrix Production, Applied Sciences-Basel 2019, 9(7):1287. https://doi.org/10.3390/app9071287 
[3] Kulcsár, G.: Ütemezési modell és heurisztikus módszerek az igény szerinti tömeggyártás finomprogramozásának támogatására, E PhD értekezés, Miskolci Egyetem, 2007.

[4] Mihály, K., Hornyák, O.: Using Graphical Processing Units in Scheduling Problems, Hungarian Journal of Industry and Chemistry 2011, 39(2):215-218.

[5] Petrovic, D., Duenas, A.: A Fuzzy Logic Based Production Scheduling/Rescheduling in the Presence of Uncertain Discruptions, Fuzzy Sets and Systems 2006, 157:2273-2285. https://doi.org/10.1016/j.fss.2006.04.009

[6] Rangsaritratsamee, R., Ferrell, W., G., Kurz, M., B.: Dynamic Rescheduling that Simultaneously Considers Efficiency and Stability, Computers and Industrial Engineering 2004, 46(1):1-15. https://doi.org/10.1016/j.cie.2003.09.007

[7] Vieira, G., Hermann, J., Lin, E.: Rescheduling Manufacturing Systems: A Framework of Strategies, Policies and Methods, E Journal of Scheduling 2003, 6(1):35-58. 